\title{
昭和48年にをける「重要存燃料関係事項」
}

\section{(Annual Fuel Reviews- (1973))}

（社）燃 料 協 会 編 集

\section{目次}

随 想(新研究開発体制の緊重性)

森川

清…(365)

1. 燃料一般

1.1 エネルギー需給の動向 $\cdots \cdots \cdots \cdots \cdots \cdots \cdots \cdots \cdots \cdots \cdots \cdots$ 日本エネルギー経済研究所…広 田 浩 $三 \cdots(367)$

1.2 工業用然料の動向

1.2 .1 電力用然料.

.電気事業連合会…米 川 惊 彦...(370)

1.2 .2 製鉄用燃料

...日本鉄鋼連盟…竹 下 栜 三...(372)

1.2.3 内燃機然料.

日本石油秼...横 山 秀 夫…(376)

1.3 家庭用燃料の動向

東京瓦斯秼…長谷部 信

康…(382)

2. 石 炭

2.1 石炭に関する研究（性状, 構造, 化学)

公害資源研究所…㞭 内 公 耳

2.2 石炭鉣業の動向.

2.3 採炭, 選炭

2.3.1 採炭技術の動向（研究を含む）

石炭技術研究所…山 村 礼次郎…(399)

2.3 .2 選炭技術の動向（研究を含む）

公害資源研究所 $\cdots$ 岩 崎 潤 二...(441)

2.4 コークス

2.4.1 コークス工業の動向

1 製鉄用コークス

日本鋼管秼) …水 野

2 製鉄用以外のコークス

通産省調查統計部…野 沢 規矩夫 …(420)

2.4 .2 コークスに関する研究

北海道工業開発試験所…吉 田

2.5 タ 一 ル

2.5.1 芳香族・タール工業の動向…

日本芳香族工業会…島 津 豊治郎…(427)

2.5.2 タールに関する研究

名古屋工業大学…吉 田 高 年...(433)

2.6 炭素工業の動向（研究を含む）

日本カーボン秼…石 川

敏 功...(436)

3. 石 油

3.1 石油に関する研究（性状，構造，化学）

東亜然料工業(雊…古 賀 雄 造…(443)

3.2 石油鉱業の動向.

石油工業連盟…松 田 省 吾…(446)

3.3 石油精製工業の動向

. 石油連盟…藤 沼

茂…(451)

3.4 石油精製に関する研究

日本石油秼…松 村

幾 敏…(456)

3.5 石油化学

3.5.1 石油化学工業の動向

通産省化学工業局…小 野

3.5 .2 石油化学に関する研究

公害資源研究所…中 中 村 悦 郎…(462)

3.6 潤 滑 油

3.6.1 潤滑油の動向（研究を含む）

日本石油秼)...山 下 正 忠…(475)

4. ガ ス

4.1 天然ガス開発利用の動向

4.1.1 天然ガス開発の動向

帝国石油秼)...鶴 田 均 三...(479)

4.1.2 天然ガス利用の動向

日本簡易ガス協会 $\cdots$ 田 辺 嘉 幸...(480)

4.2 都市ガス工業の動向

...日本瓦斯協会...遠 藤 好 得…(481)

4.3 合成ガス製造の動向

三井東圧化学秼...磯 谷 計 嘉...(490)

4.4 液化石油ガスの動向

日本 L P ガス協会 $\cdots$ 品 川 雅 弘 $\cdots$ (494)

4.5 ガス化に関する研究

早稲田大学理工学部…泉

邦 昭 $\cdots(496)$

5. 燃焼・熱管理

5.1 燃焼に関する研究 
5.1.1 固体の燃焼.......

5.1 .2 液体の然焼.

5.1 .3 気体の然焼.

5.2 熱管理の動向.
公害資源研究所…市川道 雄…(499)

群馬大学工学部…中 山 満 茂…(500)

.慶応義塾大学工学部…川口修…(502)

工業技術院技術振興課…相馬 喜代太郎…(505)

\section{6. 燃焼機器・熱機関}

6. 1 ボイラーの動向

6.1.1 火力発電用ボイラー…………………………………菱重工業珠…塩 島 誼 昌…(514)

6.1.2 一般産業用拈よび舶用ボイラー

1.

2.

6.2 工業募炉の動向

6.2 .1 製鉄用空炉.....

6.2.2 一般工業用嘿炬

6. 3 内燃機関の動向

6.3.1 陸用内燃機関

6.3.2 舶用内燃機関

6.3.3 航空用内燃機関

6.4 ガスタービンの動向

6.5 ロケットメンジン招よび推進剤の動向

6.6 家庭用ガス石油機器の動向

6.7 燃焼用自動機器の動向
.石川島播磨重工侏…齐 藤 士乃武…(519) .三菱重工陎)...深 谷 行 男…(521)

..新日本製鉄侏)...村 橋 照 善…(523) .京都大学工学部…功 刀 雅 長…(523)

7. 原子力利用

7.1 原子力利用の動向

早稲田大学理工学部…余 藤 孟…(525)

7.2 原子力資源の動向

. 明治大学工学部 $\cdots$ 藤

.石川島播磨重工業秼…伊

秀

源

雄 $\cdots(528)$

東京芝浦電気侏…本 間 友 博…(533)

日産自動車秼) …城 葍 㹂 藏 $\cdots(535)$

日本ガス機器検查協会…林 田 虎 夫…(539)

.横河電機製作所…成 願 恒 雄...(543)

7.3 濃縮の動向

日本原子力発電秼 $\cdots$. 今

動力炉・核燃料開発事業団…中

.日本原子力研究所…青

7.4 原子炬の動向

日本原子力発電秼…立

7.5 再処理の動向

核燃料開発事業団…佐 藤

隆 吉…(545)

7.6 放射性同位元素利用の動向

日本原子力研究所…川 上

穎 $三 \cdots(547)$

哲 男…(554)

昭...(556)

茂…(558)

泰…(560)

8. 新エネルギー源

8.1 $\mathrm{MHD}$ 発電の動向

.電子技術総合研究所…本

8.2 地熱発電の動向 …日本地熱調查会…伊

8.3 燃料電池の動向 名古屋大学工学部…高

8.4 太陽エネルギー利用の動向 名古屋工業技術試験所…野

8.5 海洋エネルギー利用の動向

電子技術総合研究所…本

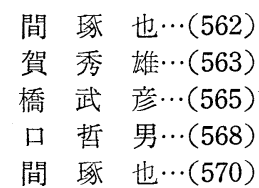

9. 公 害

9.1 大気污染対策の動向

.環境庁大気保全局…井 上 市 郎…(574)

9.2 大気污染対策の研究

9.2.1 硫黄酸化物拉よび窒素酸化物

9.2.2 自動車廃棄ガス対策…....

·産業公害防止協会…山田

剛…(578)

9.3 水質污濁対策の動向 公害資源研究所…鈴

環境水質保全局…高

9.4 水質污濁対策の研究

公害資源研究所…花

9.5 廃棄物対策の動向

.環境庁水質保全局…山

臣‥(579)

9.6 廃異物対策の研究

.公害資源研究所…市

田健

雄 $\cdots(582)$

$-\cdots(584)$

平...(586)

10. 安全対策

10.1 災害の動向

学働省安全課…野 原 石 松...(589)

10.2 安全管理の動向

横浜国立大学工学部…井 上 威 恭…(591)

11. その他

11.1 燃料に関する規格

公害資源研究所…平 塚 祐 - -...(593)

11.2 然料関する新刊書

公害資源研究所…森 田 久 三...(594)

11.3 燃料協会の活動 